\title{
Penerima Gelombang ELF berbasis Op-Amp untuk Pengolahan Akuisisi Data Gempa Bumi
}

\section{RHEYUNIARTO SAHLENDAR ASTHAN ${ }^{1}$, DEAN CORIO ${ }^{1}$, MIA MARIA ULFAH ${ }^{2}$, URI ARTA RAMADHANI ${ }^{1}$, ACHMAD MUNIR ${ }^{3}$}

\author{
1Program Studi Teknik Elektro Institut Teknologi Sumatera, Indonesia \\ 2Program Studi Teknik Telekomunikasi Institut Teknologi Sumatera, Indonesia \\ ${ }^{3}$ Laboratorium Telekomunikasi Radio dan Gelombang Mikro, Sekolah Teknik Elektro \\ dan Informatika Institut Teknologi Bandung, Indonesia \\ Email: rheyuniarto.asthan@el.itera.ac.id
}

Received 25 Januari 2021 | Revised 19 Februari 2021 | Accepted 2 April 2021

\begin{abstract}
ABSTRAK
Penelitian ini membahas mengenai penerima gelombang extremely low frequency (ELF) untuk pengolahan akuisisi data gempa bumi. Penerima ELF dirancang menggunakan operational amplifier (Op-Amp) dengan masukan takmembalik. Sinyal yang diterima oleh antena diteruskan ke penerima ELF yang terdiri dari preamplifier dan amplifier untuk proses penguatan, serta filter aktif orde 2 untuk menekan sinyal di atas frekuensi cut-off sebesar $50 \mathrm{~Hz}$. Karakterisasi penerima ELF dilakukan dengan mengamati perbandingan level tegangan sinyal keluaran terhadap level tegangan sinyal masukan, sensitivitas, serta bentuk sinyal keluaran dari penerima ELF dalam domain waktu. Hasil simulasi menunjukkan bahwa penerima ELF menghasilkan penguatan sebesar 60,8dB dengan sensitifitas tinggi untuk level sinyal masukan di bawah -30dB yang mampu memenuhi level sinyal untuk pengolahan akuisisi data.
\end{abstract}

Kata kunci: extremely low frequency, penerima ELF, operational amplifier, filter aktif, gempa bumi

\begin{abstract}
This research presents extremely low frequency (ELF) receiver for earthquake data acquisition processing. The ELF receiver is designed based on non-inverting operational amplifier (Op-Amp). The signal received by the antenna is fed into ELF receiver which consists of preamplifier and amplifier for amplification, and second order active filter to suppress unwanted signal above the cut-off frequency of $50 \mathrm{~Hz}$. Characterization of ELF receiver is performed by observing the comparison of the level output signal to level input signal, sensitivity, and $E L F$ receiver signal output in time domain. The simulation results show that the $E L F$ receiver has gain of $60.8 d B$ with high sensitivity for low level input signals below -30dB that is able to meet signal level for data acquisition processing.
\end{abstract}

Keywords: extremely low frequency, ELF receiver, operational amplifier, active filter, earthquake 
Penerima Gelombang ELF Berbasis Op-Amp untuk Pengolahan Akuisisi Data Gempa Bumi

\section{PENDAHULUAN}

Gempa bumi merupakan fenomena alam yang disebabkan oleh pelepasan energi di dalam bumi secara tiba-tiba sebagai akibat adanya pergeseran lempeng-lempeng tektonik. Energi yang dilepaskan memancar ke segala arah dan merambat melalui kerak bumi dalam bentuk gelombang seismik. Karena memiliki tingkat kedalaman yang bervariasi, gempa bumi cenderung tidak ada yang identik. Salah satu metode yang dapat digunakan untuk mengamati prekursor gempa bumi adalah melalui pengamatan emisi elektromagnetik (EM) dari litosfer (Hayakawa \& Hobara, 2010). Aktivitas seismik sebelum terjadi gempa bumi ditandai dengan adanya anomali medan magnetik serta kerapatan elektron (De Santis, dkk, 2019), dan/atau anomali gradien potensial medan listrik (Smirnov, 2020). Emisi EM sebelum gempa bumi terjadi berada pada rentang frekuensi hertz hingga megahertz (Mullayarov, dkk, 2014) (Petraki, dkk, 2015) (Zhima, dkk, 2020).

Pada dasarnya, gelombang EM frekuensi rendah dapat menembus permukaan bumi dan merambat pada lapisan ionosfer dengan redaman rendah, sementara pada frekuensi tinggi gelombang akan mengalami fluktuasi seiring dengan perubahan jarak terhadap sumber karena kemampuan penetrasi (skin depth) dari gelombang EM semakin rendah (Hayt \& Buck, 2012). Penggunaan frekuensi rendah pada pita ultra low frequency (ULF) dan/atau extremely low frequency (ELF) untuk karakterisasi gempa bumi menjadi sangat menjanjikan karena telah banyak data hasil penelitian yang menyatakan bahwa gempa bumi skala tinggi terjadi pada pita frekuensi tersebut (Hayakawa, dkk, 2008). Melalui studi mengenai perubahan medan magnetik terkait kegempaan pada rentang frekuensi ULF hingga ELF, Schekotov (Schekotov, dkk, 2007) dan timnya mengemukakan bahwa emisi pita lebar ditemukan sebelum dan setelah terjadi gempa bumi. Sementara itu, hasil penelitian yang dilakukan oleh Ohta (Ohta, dkk, 2013) dan timnya menunjukkan bahwa emisi gelombang radio ULF/ELF menjadi prekursor gempa bumi besar yang terjadi di Jepang pada tahun 2011.

Gelombang EM yang dieksitasi oleh gelombang seismik ditangkap oleh antena penerima dengan level yang sangat kecil, yaitu di bawah mikrowatt (Putera, dkk, 2014) (Munir, dkk, 2017). Untuk menjamin bahwa gelombang yang diterima memenuhi level amplituda minimum untuk proses akuisisi data, maka dibutuhkan sebuah perangkat penerima yang handal dengan sensitivitas dan penguatan tinggi serta noise rendah. Deteksi emisi EM melalui parameter kerapatan fluks magnetik telah dilakukan oleh Tsutsui (Tsutsui, 2014) dengan menghubungkan antena kawat ke sebuah perangkat penerima dengan penguatan sebesar $>60 \mathrm{~dB}$. Tidak hanya digunakan untuk karakterisasi emisi EM sebagai prekursor gempa bumi, perangkat penerima dengan penguatan tinggi juga diperlukan untuk aplikasi ELF lainnya, seperti deteksi gelombang resonansi Schuman (Sierra, dkk, 2014). Pemilihan komponen penyusun perangkat penerima ELF menjadi sangat penting karena perangkat penerima pada frekuensi rendah cenderung sensitif terhadap noise. Penerima ELF dapat dirancang menggunakan operational amplifier (Op-Amp) dengan umpan balik yang kemudian disusun secara bertingkat untuk menghasilkan penguatan tinggi (Votis, dkk, 2018). Penguatan yang stabil dan akurat dapat dicapai dengan mudah melalui pengaturan rasio antara komponen resistor yang terhubung dengan Op-Amp melalui hubungan umpan balik (Franco, 2015).

Pada penelitian ini dilakukan perancangan penerima ELF untuk akuisisi data gempa bumi yang beroperasi pada rentang frekuensi $1 \mathrm{~Hz}$ sampai dengan $50 \mathrm{~Hz}$. Penelitian ini merupakan kelanjutan dari penelitian yang telah dilakukan oleh Asthan (Asthan, dkk, 2020) dan 
timnya. Penerima ELF dimaksudkan untuk menguatkan gelombang ELF yang diterima oleh antena dengan menekan distorsi yang mungkin terjadi akibat perbedaan frekuensi maupun fluktuasi level sinyal yang diterima. Penekanan pada distorsi tersebut diharapkan berpengaruh terhadap representasi data dari emisi EM pada saat pengolahan sinyal dilakukan melalui perangkat akuisisi data. Penerima ELF terdiri dari penguat bertingkat dan filter yang masing-masing dikonfigurasi menggunakan komponen aktif berupa Op-Amp yang dirangkaikan dengan lumped element. Karakterisasi penerima ELF terkait sensitivitas dilakukan dengan membandingkan level sinyal masukan dan level sinyal keluaran, sementara pengukuran penguatan hasil simulasi dilakukan untuk setiap sub-sistem penyusun penerima ELF. Analisis sinyal pada domain waktu juga dilakukan untuk mengetahui pengaruh penerima ELF terhadap perubahan level tegangan sinyal masukan.

\section{METODOLOGI PENELITIAN}

\subsection{Sistem Penerima ELF}

Penerima ELF terdiri dari rangkaian preamplifier, filter aktif dengan respon karakteristik lowpass serta amplifier, seperti yang ditunjukkan pada Gambar 1. Gelombang ELF yang ditangkap oleh antena diteruskan ke penerima ELF untuk proses penguatan dan penyaringan. Untuk menjaga agar level tegangan keluaran tidak mengalami saturasi sebagai akibat dari level sinyal masukan pada penerima ELF yang sangat kecil, yaitu di bawah mikrowatt, maka penguatan sinyal dilakukan secara bertingkat melalui rangkaian preamplifier dan amplifier. Dengan demikian, sistem yang dirancang menjadi lebih stabil dan terkontrol. Rangkaian penyusun penerima ELF dirancang menggunakan OP27 karena memiliki performansi yang baik dengan noise rendah untuk level sinyal masukan kecil (Analog Devices, 2015). Karena rangkaian preamplifier memiliki penguatan yang stabil pada rentang frekuensi rendah di bawah kilohert, maka dibutuhkan rangkaian low-pass filter (LPF) aktif untuk menekan level sinyal pada frekuensi di luar fekuensi yang tidak diinginkan yang muncul akibat perbedaan frekuensi pada sinyal yang diterima. Rangkaian ini juga dimaksudkan untuk meminimalisir noise yang mungkin muncul pada frekuensi rendah. Total penguatan yang diharapkan secara keseluruhan dari penerima ELF adalah sebesar $60 \mathrm{~dB}$ pada rentang frekuensi yang diinginkan yaitu $1 \mathrm{~Hz}$ sampai $50 \mathrm{~Hz}$. Untuk sinyal masukan antena dengan level di bawah mikrowatt, besarnya penguatan yang diusulkan dianggap mencukupi untuk menghasilkan sinyal dengan level di atas miliwatt dengan asumsi bahwa antena memiliki penguatan (gain) yang baik sehingga sinyal keluaran dari penerima ELF dapat diproses lebih lanjut oleh perangkat akuisisi data. Sementara itu, apabila ditinjau dari spektrum frekuensi radio, sistem penerima yang disulkan masih mencakup rentang frekuensi gelombang ELF berada yaitu frekuensi $3 \mathrm{~Hz}$ sampai $300 \mathrm{~Hz}$ dengan panjang gelombang sebesar 1000 kilometer sampai 100000 kilometer.

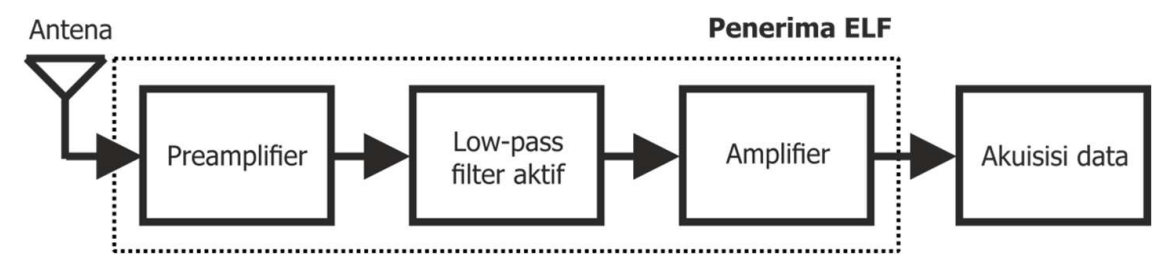

\section{Gambar 1. Blok Diagram Penerima ELF}

\subsection{Perancangan Penerima ELF}

\subsubsection{Rangkaian Preamplifier}

Rangkaian preamplifier dirancang menggunakan Op-Amp OP27 dengan masukan takmembalik untuk menghasilkan penguatan sebesar $40 \mathrm{~dB}$ pada rentang frekuensi $1 \mathrm{~Hz}$ sampai 
$50 \mathrm{~Hz}$. Niilai penguatan $(K)$ yang dihasilkan ditentukan oleh rasio antara $R_{7}$ dan $R_{8}$, seperti yang ditunjukkan pada Persamaan (1). Untuk menghasilan $K$ sebesar $40 \mathrm{~dB}$, maka digunakan nilai $R_{7}$ dan $R_{8}$ masing-masing adalah $100 \mathrm{k} \Omega$ dan $1 \mathrm{k} \Omega$. Dalam perancangannya, rangkaian preamplifier dilengkapi dengan kapasitor bypass untuk menyaring noise AC yang mungkin muncul dari sumber tegangan sehingga sinyal DC murni dengan level tegangan sebesar \pm 15VDC dapat dihasilkan dan menjadi masukan OP27 pada pin 4 (VEE) dan pin 7 (VCC), seperti yang ditunjukkan pada Gambar 2. Selain itu, filter pasif menggunakan komponen $R_{9}$ dan $C_{9}$ juga ditambahkan dan ditempatkan setelah preamplifier untuk menghilangkan flicker noise.

$$
K_{\text {preamp }}(\mathrm{dB})=20 \log \left(1+\frac{R_{7}}{R_{8}}\right)
$$

\subsubsection{Rangkaian Low-Pass Filter Aktif}

Pada penerima ELF, rangkaian filter berfungsi untuk menyaring sinyal pada frekuensi yang tidak diinginkan. Rangkaian filter disusun menggunakan komponen aktif berupa Op-Amp, dikenal sebagai filter aktif, yang dirangkaikan dengan kompenen resistor dan kapasitor. Untuk aplikasi pada frekuensi rendah, filter aktif cenderung memiliki keunggulan dibandingkan filter pasif. Apabila filter pasif diterapkan pada frekuensi rendah dimana dibutuhkan faktor kualitas yang cukup, maka sistem akan mengalami saturasi dan menghasilkan efek distorsi non-linear sebagai akibat meningkatnya nilai induktansi. Selain itu, penurunan level sinyal menjadi sangat tinggi apabila filter pasif dikonfigurasi dengan multi-tingkat. Berbeda halnya dengan filter pasif, filter aktif memiliki impedansi masukan tinggi dan impedansi keluaran rendah yang memungkinkan susunan multi-tingkat.

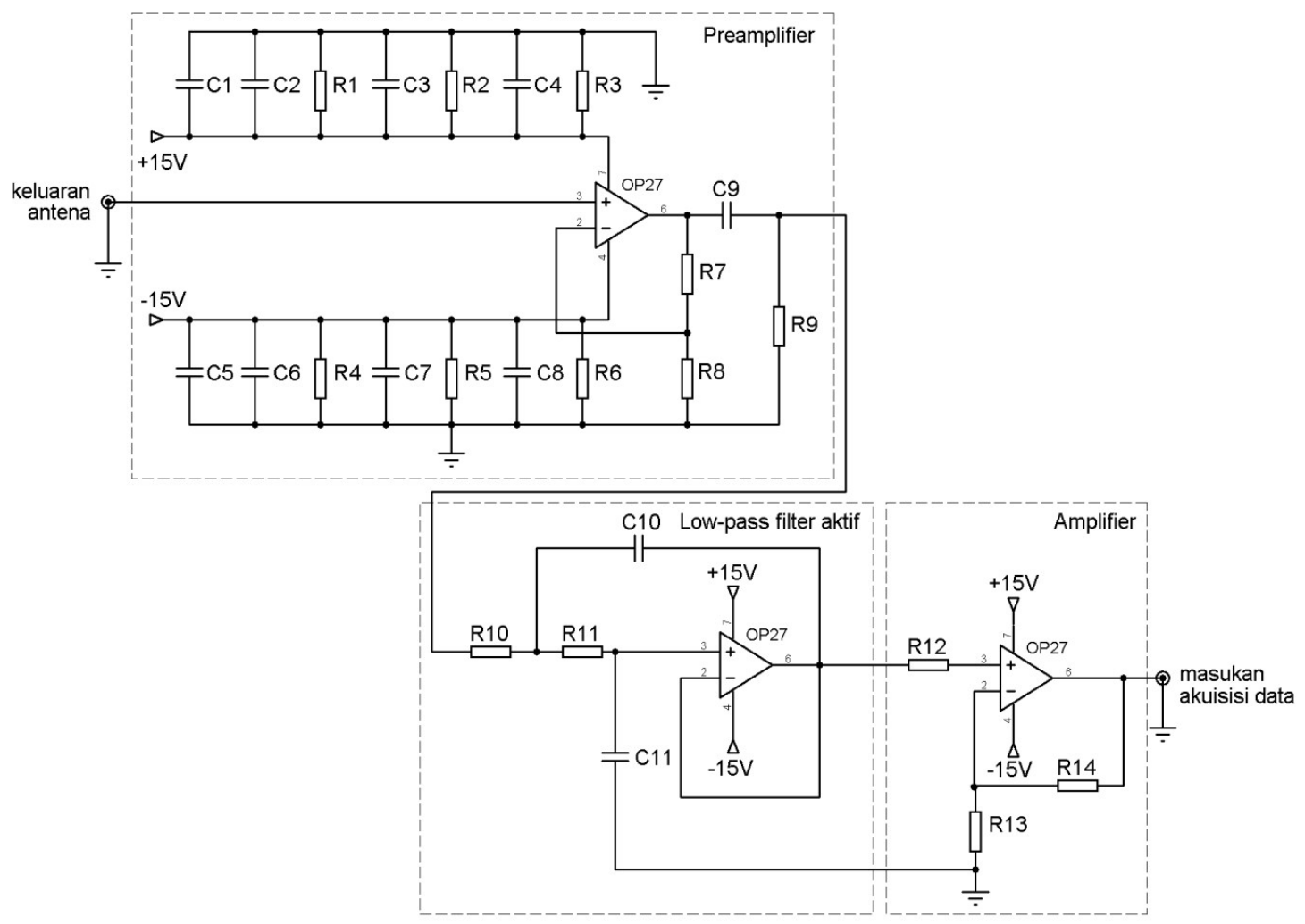

Gambar 2. Diagram Skematik Penerima ELF 
Filter aktif dirancang untuk menghasilkan respon karakteristik Butterwoth low-pass dengan frekuensi cut-off sebesar $50 \mathrm{~Hz}$ yang menyatakan bahwa pada frekuensi tersebut level tegangan keluaran akan mengalami penurunan level sebesar 3dB dari level tegangan puncaknya. Pada penerima ELF, rangkaian filter menggunakan Op-Amp juga difungsikan sebagai buffer amplifier dengan $K$ sebesar 1 atau tanpa penguatan (unity gain). Hal ini dimaksudkan untuk mengatasi ketidaksesuaian antara impedansi masukan rangkaian filter dengan impedansi keluaran dari rangkaian preamplifier. Apabila impedansi tidak sesuai, maka sinyal yang diteruskan ke rangkaian filter akan mengalami penurunan level tegangan, dengan demikian penguatan yang dihasilkan tidak lagi menjadi linear.

Filter aktif dikonfigurasi menggunakan topologi Sallen-Key orde 2, seperti yang ditunjukkan pada Gambar 2. Dalam perancangannya, respon filter dinormalisasi dengan membagi elemen reaktif dengan frequency-scaling factor (FSF) dan impedance-scaling factor (ISF). Nilai komponen penyusun rangkaian sebagai elemen reaktif ditentukan menggunakan Persamaan (2)-(7) (Pactitis, 2007), dimana $C_{10 \text { n }}$ dan $C_{11 \text { n }}$ masing-masing adalah nilai normalisasi dari $C_{10}$ dan $C_{11}, K$ adalah penguatan (tanpa satuan), $a$ dan $b$ merupakan koefisien Butterworth dengan nilai masing-masing adalah 1,414 dan 1 untuk filter orde $2(n=2)$, sedangkan $R_{\mathrm{n}}$ dan $\omega_{\mathrm{n}}$ merupakan nilai denormalisasi dari $R$ dan $\omega$. Sementara $f$ menyatakan frekuensi cut-off dari filter yang akan dirancang, yaitu sebesar $50 \mathrm{~Hz}$. Dalam perancangannya, nilai $R$ ditentukan terlebih dahulu yaitu sebesar $10 \mathrm{k} \Omega$, dimana nilai tersebut merepresentasikan nilai komponen $R_{10}$ dan $R_{11}$. Nilai yang dipilih disesuaikan dengan nilai komponen yang tersedia dipasaran.

$$
\begin{aligned}
& C_{10 n}=\frac{4}{a+\sqrt{a^{2}+8 b(K-1)}} \\
& C_{11 n}=\frac{a+\sqrt{a^{2}+8 b(K-1)}}{4 b} \\
& \mathrm{FSF}=\frac{\omega}{\omega_{n}}=\frac{2 \pi f}{1}=2 \pi f \\
& \mathrm{ISF}=\frac{R}{\omega_{n}}=\frac{R}{1}=R \\
& C_{10}=\frac{C_{10 n}}{\mathrm{ISF} \times \mathrm{FSF}} \\
& C_{11}=\frac{C_{11 n}}{\mathrm{ISF} \times \mathrm{FSF}}
\end{aligned}
$$

Berdasarkan data hasil perhitungan menggunakan Persamaan (2)-(7), diperoleh nilai $C_{10}$ dan $C_{11}$ yang masing-masing adalah sebesar $450 \mathrm{nF}$ dan $225 \mathrm{nF}$. Dalam perancangannya, nilai komponen yang digunakan pada proses simulasi disesuaikan dengan nilai komponen kapasitor yang tersedia dipasaran, namun tentu saja nilainya tidak memiliki perbedaan yang signifikan terhadap nilai hasil perhitungan. Dalam hal ini, nilai yang digunakan adalah $C_{10}$ sebesar $470 \mathrm{nF}$ dan $C_{11}$ sebesar $220 \mathrm{nF}$. Perlu diketahui bahwa dengan mengubah nilai kapasitor menjadi lebih besar, maka frekuensi cut-off akan begeser ke frekuensi yang lebih tinggi dan begitupun sebaliknya.

\subsubsection{Rangkaian Amplifier}

Level tegangan keluaran dari rangkaian filter kemudian ditingkatkan menggunakan rangkaian amplifier untuk memenuhi spesifikasi perancangan. Sama halnya dengan rangkaian preamplifier, rangkaian amplifier dirancang menggunakan OP27 dengan masukan 
tak-membalik. Dengan mengatur rasio antara $R_{13}$ dan $R_{14}$, seperti yang dinyatakan pada Persamaan (8), penguatan sebesar $20,8 \mathrm{~dB}$ dapat dihasilkan. Nilai $R_{13}$ dan $R_{14}$ yang digunakan masing-masing adalah sebesar $10 \mathrm{k} \Omega$ dan $100 \mathrm{k} \Omega$. Pada rangkaian amplifier, $R_{14}$ berperan sebagai resistor umpan balik. Keluaran dari rangkaian amplifier ini akan menjadi masukan perangkat akuisisi data untuk proses lebih lanjut. Nilai komponen penerima ELF dari hasil perancangan ditunjukkan pada Tabel 1 . Seluruh nilai komponen yang digunakan pada simulasi telah disesuaikan dengan nilai komponen yang tersedia dipasaran.

$$
K_{\mathrm{amp}}(\mathrm{dB})=20 \log \left(1+\frac{R_{14}}{R_{13}}\right)
$$

Tabel 1. Nilai Komponen Pada Skematik Penerima ELF

\begin{tabular}{|c|c|c|c|}
\hline Komponen & Nilai $(\boldsymbol{\Omega})$ & Komponen & Nilai (F) \\
\hline$R_{1}$ & $100 \mathrm{k}$ & $C_{1}$ & $470 \mu$ \\
\hline$R_{2}$ & $100 \mathrm{k}$ & $C_{2}$ & $100 \mathrm{n}$ \\
\hline$R_{3}$ & $100 \mathrm{k}$ & $C_{3}$ & $100 \mathrm{n}$ \\
\hline$R_{4}$ & $100 \mathrm{k}$ & $C_{4}$ & $100 \mathrm{n}$ \\
\hline$R_{5}$ & $100 \mathrm{k}$ & $C_{5}$ & $470 \mu$ \\
\hline$R_{6}$ & $100 \mathrm{k}$ & $C_{6}$ & $100 \mathrm{n}$ \\
\hline$R_{7}$ & $100 \mathrm{k}$ & $C_{7}$ & $100 \mathrm{n}$ \\
\hline$R_{8}$ & $1 \mathrm{k}$ & $C_{8}$ & $100 \mathrm{n}$ \\
\hline$R_{9}$ & $10 \mathrm{M}$ & $C_{9}$ & $47 \mu$ \\
\hline$R_{10}$ & $10 \mathrm{k}$ & $C_{10}$ & $470 \mathrm{n}$ \\
\hline$R_{11}$ & $10 \mathrm{k}$ & $C_{11}$ & $220 \mathrm{n}$ \\
\hline$R_{12}$ & $1 \mathrm{k}$ & - & - \\
\hline$R_{13}$ & $10 \mathrm{k}$ & - & - \\
\hline$R_{14}$ & $100 \mathrm{k}$ & - & - \\
\hline
\end{tabular}

\section{HASIL DAN PEMBAHASAN}

Pada penelitian ini, performansi dari rancangan penerima ELF dianalisis berdasarkan data hasil simulasi yang memuat level tegangan keluaran. Parameter tersebut kemudian digunakan untuk menentukan besarnya nilai penguatan yang dihasilkan serta sensitivitas penerima pada rentang frekuensi $1 \mathrm{~Hz}$ hingga $500 \mathrm{~Hz}$. Nilai penguatan ( $K_{\text {out }}$ ) hasil simulasi diperoleh dengan membandingkan level tegangan keluaran $\left(V_{0}\right)$ terhadap level tegangan masukan ( $\left.V_{i}\right)$ menggunakan Persamaan (9).

$$
K_{\text {out }}(\mathrm{dB})=20 \log \left(\frac{V_{\mathrm{o}}}{V_{\mathrm{i}}}\right)
$$

Hasil simulasi penguatan dari rangkaian preamplifier dan amplifier ditunjukkan pada Gambar 3. Sinyal masukan adalah sinyal sinusoidal dengan level sebesar $-40 \mathrm{dBm}$, dimana dianggap bahwa nilai tersebut telah merepresentasikan level sinyal yang diterima oleh antena sebelum diteruskan ke penerima ELF. Hasil simulasi menunjukkan bahwa rangkaian preamplifier dan amplifier menghasilkan nilai penguatan konstan pada rentang frekuensi yang diamati yaitu masing-masing sebesar $40 \mathrm{~dB}$ dan $20,8 \mathrm{~dB}$. Sementara sinyal yang melewati rangkaian filter dengan respon karakteristik low-pass memiliki penguatan sebesar $0 \mathrm{~dB}$ pada rentang frekuensi $1 \mathrm{~Hz}$ hingga $20 \mathrm{~Hz}$ dan kemudian secara perlahan mengalami penurunan pada frekuensi yang lebih tinggi, khususnya di atas frekuensi cut-off, seperti yang ditunjukkan pada Gambar 4. Respon karakteristik yang tidak ideal sebagai akibat dari penggunaan filter orde rendah $(n=2)$ menyebabkan penekanan level sinyal masukan filter tidak akan maksimum di frekuensi cut-off sebesar $50 \mathrm{~Hz}$. Hal ini disebabkan karena filter orde rendah 
cenderung kurang sensitif terhadap kesalahan akurasi sehingga lebar daerah transisi yang dihasilkan lebih lebar. Performansi filter dapat ditingkatkan dengan memperbesar orde filter sehingga faktor selektivitas dan laju roll-off dari filter yang dirancang meningkat serta menghasilkan lebar daerah transisi yang sempit. Namun, semakin tinggi orde filter, maka kompleksitas dalam perancangan dan implementasi juga akan semakin meningkat.

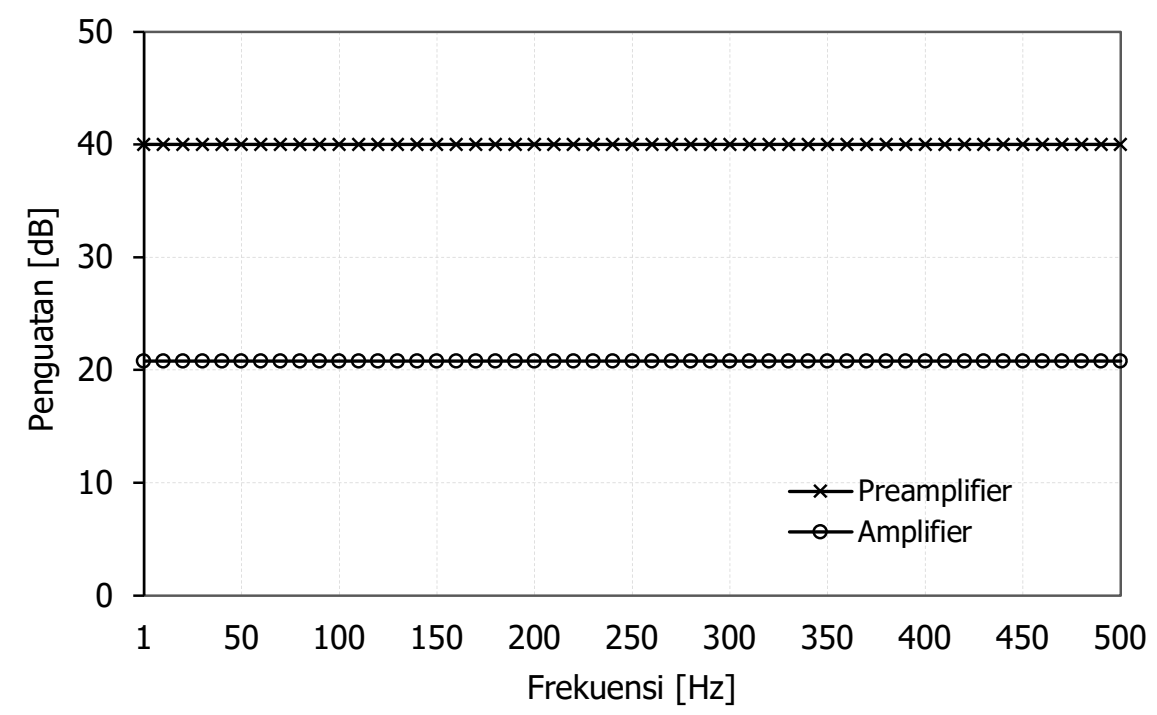

Gambar 3. Hasil Simulasi Penguatan Rangkaian Preamplifier dan Amplifier

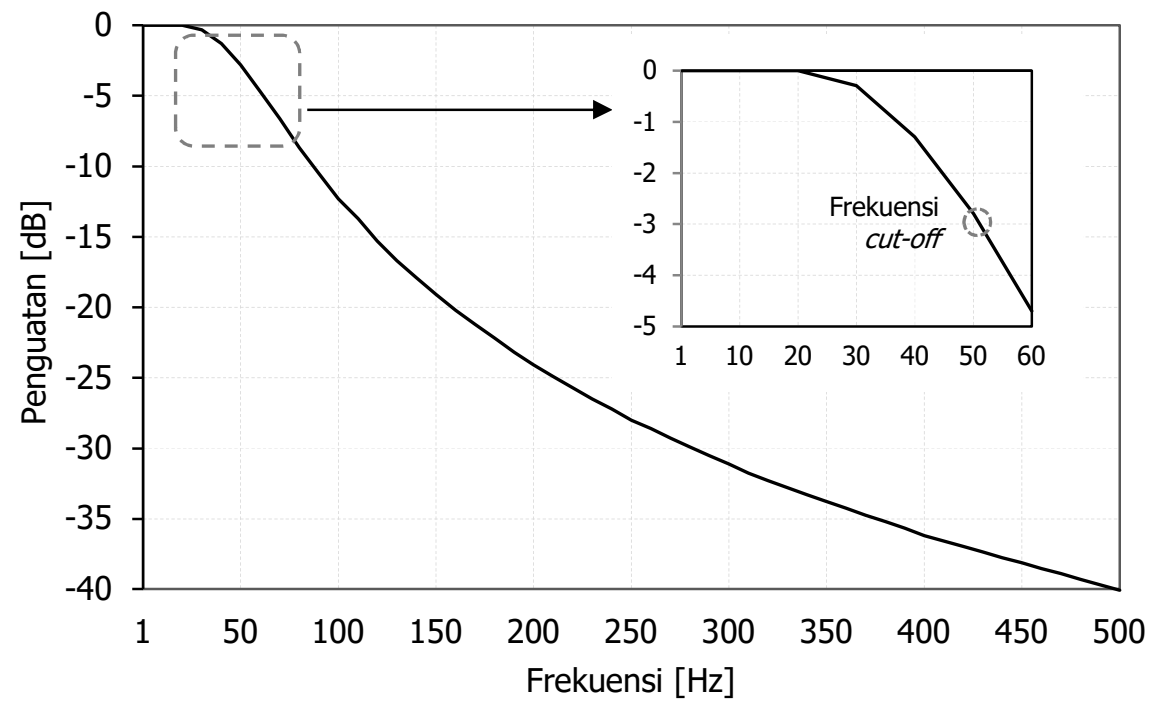

Gambar 4. Hasil Simulasi Frekuensi Cut-off Rangkaian Low-Pass Filter Aktif

Rancangan penerima ELF memiliki penguatan yang stabil untuk level sinyal masukan yang berbeda dengan penguatan maksimum sebesar 60,8dB untuk frekuensi di bawah frekuensi cut-off, seperti yang ditunjukkan pada Gambar 5. Karena sinyal keluaran dari preamplifier dilewatkan pada rangkaian filter dan kemudian dikuatkan kembali oleh rangkaian amplifier, maka level sinyal keluaran dari penerima ELF akan mengalami pelemahan sinyal mengikuti respon karakteristik dari rangkaian filter. Pada proses simulasi, sinyal keluaran diamati untuk mengetahui pengaruh karakteristik penerima ELF terhadap level tegangan sinyal masukan. Sinyal masukan berupa sinyal sinusoidal dengan level sebesar $-30 \mathrm{dBm}$ pada frekuensi $20 \mathrm{~Hz}$. Hasil simulasi menunjukkan bahwa level sinyal keluaran menjadi lebih besar dibandingkan 
level sinyal masukan, seperti yang ditunjukkan pada Gambar 6(a). Hal ini menyatakan bahwa penerima ELF berfungsi sebagai penguat sinyal. Pada kasus deteksi gempa bumi, fluktuasi signifikan pada level sinyal yang diterima oleh antena umumnya jarang terjadi karena level sinyal yang diterima sebelum diteruskan ke perangkat penerima memiliki level yang sangat kecil. Namun, pada kasus dimana terdapat perbedaan frekuensi pada sinyal yang diterima, maka sinyal tersebut dapat mengalami distorsi. Hal tersebut dapat diatasi dengan menggunakan filter. Adapun jika terjadi fluktuasi level sinyal yang diterima yang bisa mengakibatkan level sinyal keluaran melebihi nilai tegangan DC Op-Amp pada pin 4 dan pin 7 , yaitu $-15 \mathrm{~V}$ hingga $+15 \mathrm{~V}$, maka sinyal keluaran akan mengalami pemotongan atau clipping, seperti yang ditunjukkan pada Gambar 6(b). Guna mengantisipasi hal tersebut, penggunaan potensiometer sebagai pengganti komponen $R_{14}$ pada rangkaian amplifier dapat diterapkan untuk menjaga rasio antara resistor umpan balik dengan resistor $R_{13}$.

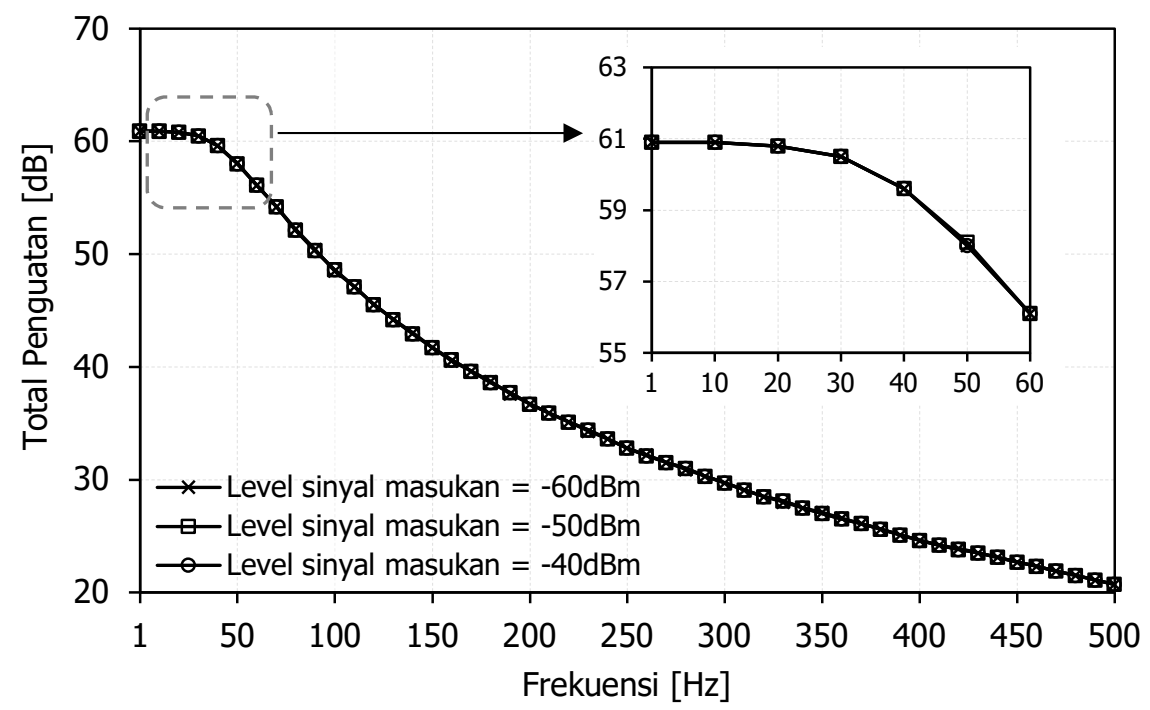

Gambar 5. Hasil Simulasi Total Penguatan Penerima ELF

Kemampuan penerima ELF dalam mendeteksi gelombang elektromagnetik dengan level sinyal yang sangat rendah dianalisis melalui parameter sensitifitas. Sensitifitas penerima diukur untuk level sinyal masukan yaitu $-60 \mathrm{dBm}$ hingga $-30 \mathrm{dBm}$, seperti yang ditunjukkan pada Gambar 7. Hasil simulasi menunjukkan bahwa tegangan keluaran sinyal meningkat secara linear untuk setiap level sinyal masukan yang berbeda-beda. Untuk level sinyal masukan minimum sebesar $-60 \mathrm{dBm}$, sinyal keluaran memiliki tegangan sebesar $0,5 \mathrm{Vpp}$ hingga $0,69 \mathrm{Vpp}$, sedangkan tegangan keluaran maksimum dihasilkan untuk level sinyal masukan $-30 \mathrm{dBm}$, yaitu $15,8 \mathrm{Vpp}$ hingga $21,72 \mathrm{Vpp}$. Hal ini menyatakan bahwa rancangan penerima ELF memiliki sensitifitas tinggi untuk frekuensi pada rentang $1 \mathrm{~Hz}$ hingga $50 \mathrm{~Hz}$ sesuai dengan spesifikasi perancangan. Variasi level tegangan pada frekuensi yang lebih tinggi yaitu $40 \mathrm{~Hz}$ hingga $50 \mathrm{~Hz}$ disebabkan karena penerima ELF dilengkapi dengan rangkaian low-pass filter aktif yang memiliki respon karakteristik tidak ideal. Meskipun demikian, rancangan penerima ELF masih dapat diandalkan untuk mendeteksi emisi EM yang dieksitasi oleh gempa bumi. Karena hasil simulasi menunjukkan performansi yang baik dilihat dari sensitivitas dan penguatan, maka selanjutnya dapat dilakukan realisasi dan pengukuran penerima ELF. 


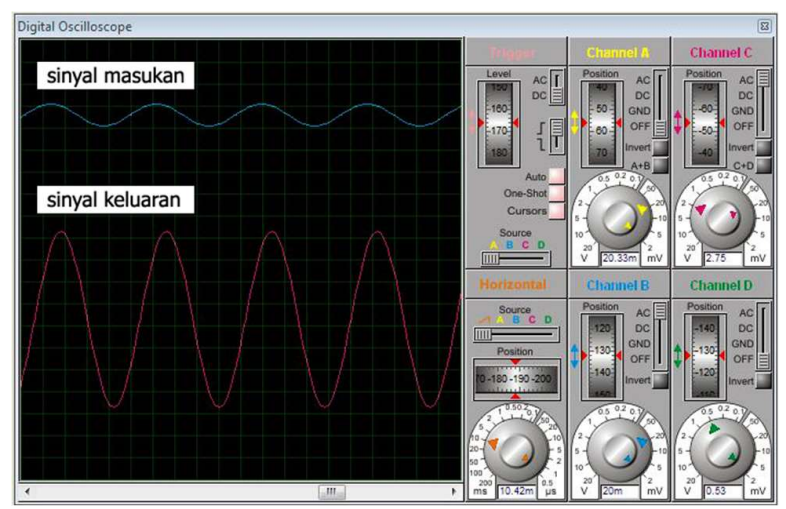

(a)

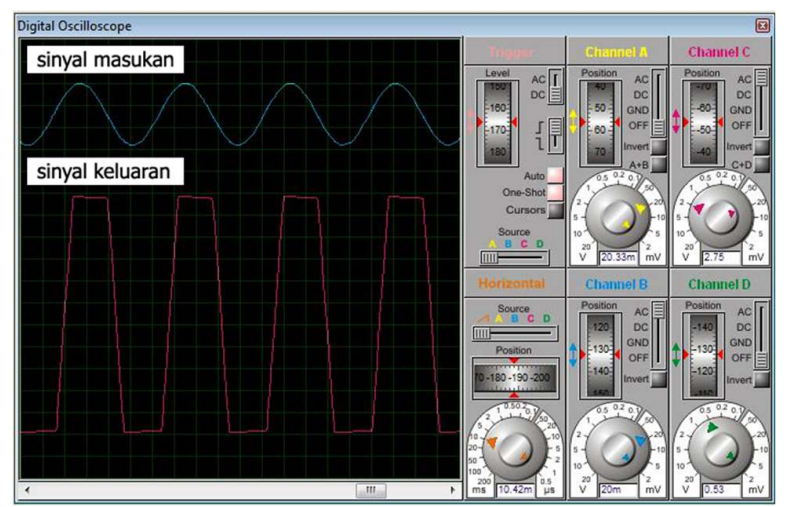

(b)

Gambar 6. Hasil Simulasi Sinyal Keluaran Penerima ELF, (a) Tanpa Distorsi, (b) Dengan Distorsi

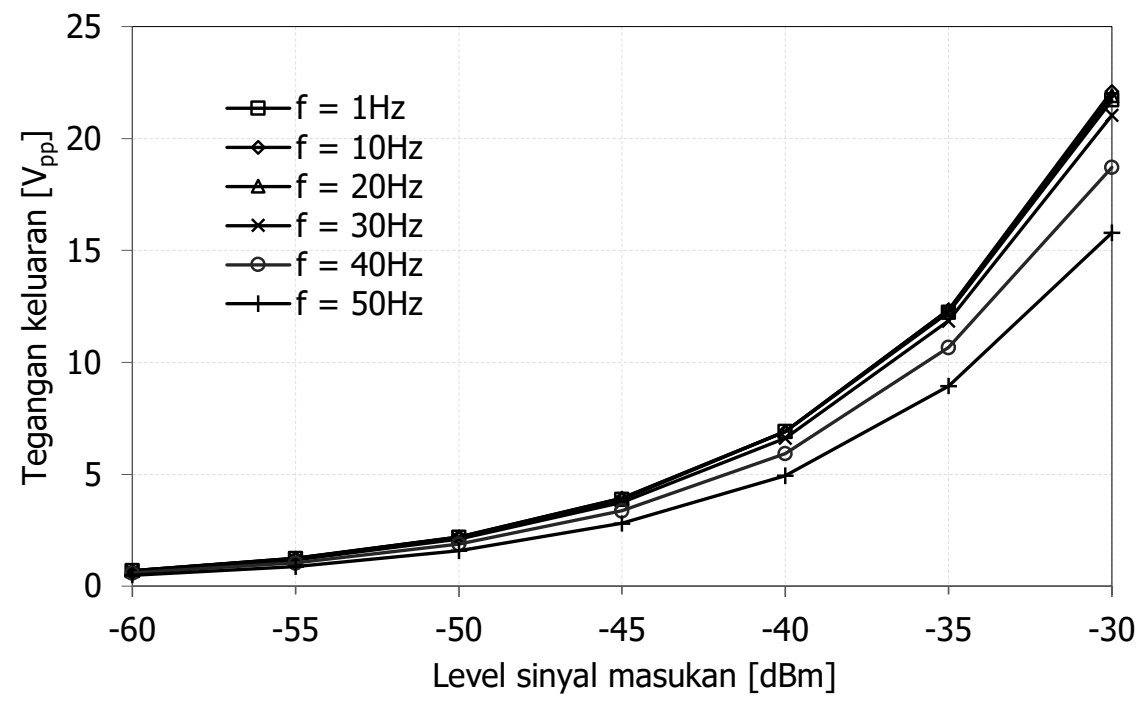

Gambar 7. Hasil Simulasi Sensitifitas Penerima ELF

Rangkaian penyusun pada penerima ELF dapat direalisasikan pada sebuah printed circuit board menggunakan nilai komponen resistor dan kapasitor yang dimuat pada Tabel 1 . Nilai komponen tersebut telah disimulasikan dengan mempertimbangkan ketersediaan komponen, kemudahan dalam proses fabrikasi, serta kesesuaian hasil simulasi terhadap spesifikasi yang diharapkan. Pemilihan komponen resistor dan kapasitor yang mengadopsi tipe surface mount 
device (SMD) juga dapat dipertimbangkan untuk memperkecil dimensi perangkat. Sementara itu, sumber tegangan masukan OP27 sebesar $\pm 15 V D C$ dapat direalisasikan dengan baterai $12 \mathrm{~V}$ yang dirangkaikan dengan konverter DC-DC menggunakan NMH1215S untuk menghasilkan tegangan bias yang simetris sesuai dengan kebutuhan OP27. Dengan demikian, diharapkan adanya kesesuaian antara hasil pengukuran setelah fabrikasi dengan hasil simulasi yang telah dilakukan.

\section{KESIMPULAN}

Penerima ELF berbasis Op-Amp dengan masukan tak membalik yang terdiri dari rangkaian penguat bertingkat serta filter telah dirancang dan disimulasikan menggunakan OP27. Hasil simulasi menunjukkan bahwa penerima ELF yang diusulkan memiliki penguatan serta sensitivitas tinggi untuk level sinyal masukan yang kecil pada rentang frekuensi yang diinginkan. Karena telah memenuhi spesifikasi yang diinginkan, penerima ELF ini dapat diusulkan untuk pengolahan akuisisi data gempa bumi. Implementasi dan karakterisasi rancangan melalui proses pengukuran untuk mengetahui kinerja dari penerima ELF secara keseluruhan akan dilakukan kemudian.

\section{UCAPAN TERIMA KASIH}

Penelitian ini dibiayai penuh oleh Lembaga Penelitian, Pengabdian kepada Masyarakat, dan Penjaminan Mutu Pendidikan (LP3) Institut Teknologi Sumatera melalui hibah penelitian ITERA SMART nomor B/322/IT9.C1/PT.01.03/2019.

\section{DAFTAR RUJUKAN}

Analog Devices. (2015). Low Noise, Precision Operational Amplifier. OP27 datasheet, Rev. H. Retrieved from https://www.analog.com/media/en/technical-documentation/datasheets/op27.pdf.

Asthan, R. S., Corio, D., Ulfah, M. M., Ramadhani, U. A., Kusmadi, \& Munir, A. (2020). Design and Characterization of High Gain Amplifier for ELF Receiver Application. The 14th International Conference on Telecommunication Systems, Services, and Application (TSSA), (pp. 1-4).

De Santis, A., D., Marchetti, D., Pavon-Carrasco, F. J., Cianchini, G., Perrone, L., Abbattista, C., ... Haagmans, R. (2019). Precursory Worldwide Signatures of Earthquake Occurrences on Swarm Satellite Data. Scientific Reports 9, Article 20287. https://doi.org/10.1038/s41598-019-56599-1.

Franco, S. (2015). Design with Operational Amplifiers and Analog Integrated Circuits, 4th ed. New York: McGraw-Hill.

Hayakawa, M. \& Hobara, Y. (2010). Current Status of Seismo-electromagnetics for Shortterm Earthquake Prediction. Geomatics, Natural Hazards and Risk, 1(2), 115-155. 
Hayakawa, M., Nickolaenko, A. P., Sekiguchi, M., Yamashita, K., Ida, Y., \& Tyano, M. (2008). Anomalous ELF Phenomena in the Schumann Resonance Band as Observed at Moshiri (Japan) in Possible Association with an Earthquake in Taiwan. Natural Hazards and Earth System Sciences, 8, 1309-1316.

Hayt, W. H., \& Buck, J. A. (2012). Engineering Electromagnetics (8th ed.). New York: McGraw-Hill.

Mullayarov, V. A., Druzhin, G. I., Argunov, V. V., Abzaletdinova, L., M., \& Mel'nikov, A. N. (2014). Variations of VLF Radio Signals and Atmospherics During the Deep Earthquake with $M=8.2$ Occured on 24 May 2013 Near Kamchatka Peninsula. Natural Science, 6(3), 144-149. https://doi.org/10.4236/ns.2014.63019.

Munir, A., Kusmadi, Kusnandar, Najmurrokhman, A., Chairunnisa, \& Sunubroto. (2017). High Sensitivity Very Low Frequency Receiver for Earthquake Data Acquisition. TELKOMNIKA: Telecommunication, Computing, Electronics and Control, 15(1), 151155.

Ohta, K., Izutsu, J., Schekotov, A., \& Hayakawa, M. (2013). The ULF/ELF Electromagnetic Radiation Before the 11 March 2011 Japanese Earthquake. Radio Science, 48(5), 589-596. https://doi.org/10.1002/rds.20064.

Pactitis, S. A. (2007). Active Filters: Theory and Design. Boca Raton: CRC Press, Taylor \& Francis Group.

Petraki E., Nikolopoulos D., Nomicos C., Stonham J., Cantzos D., Yannakopoulos P., \& Kottou S. (2015). Electromagnetic Pre-earthquake Precursors: Mechanisms, Data and Models-A Review. Journal of Earth Science \& Climatic Change, 6(1). https://doi.org/10.4172/2157-7617.1000250.

Putera, R., Kusnandar, A., Najmurrokhman, Sunubroto, Chairunnisa, \& Munir, A. (2014). High Gain RF Amplifier for Very Low Frequency Receiver Application. 6th International Conference on Information Technology and Electrical Engineering (ICITEE), (pp. 14).

Schekotov, A. Y., Molchanov, O. A., Hayakawa, M., Fedorov, E. N., Chebrov, V. N., Sinitsin, V. I., ... Yagova, N. V. (2007). ULF/ELF Magnetic Field Variations from Atmosphere Induced by Seismicity. Radio Science, 42(6). https://doi.org/10.1029/2005RS003441.

Sierra, F. P., Vazquez, H. S., Andrade, M. E., Mendoza, B., \& Rodriguez-Ozario, D. (2014). Development of a Schumann-resonance Station in Mexico: Preliminary Measurements. IEEE Antennas and Propagation Magazine, 56(3), 112-119. 
Penerima Gelombang ELF Berbasis Op-Amp untuk Pengolahan Akuisisi Data Gempa Bumi

Smirnov, S. (2020). Negative Anomalies of the Earth's Electric Field as Earthquake Precursors. Geosciences 2020, 10(1). https://doi.org/10.3390/geosciences10010010.

Tsutsui, M. (2014). Behaviors of Electromagnetic Waves Directly Excited by Earthquakes. IEEE Geoscience and Remote Sensing Letters, 11(1), 1961-1965.

Votis, C. I., Tatsis, G., Christofilakis, V., Chronopoulos, S. K., Kostarakis, P., Tritakis, V., \& Repapis, C. (2018). A New Portable ELF Schumann Resonance Receiver: Design and Detailed Analysis of the Antenna and the Analog Front-end. EURASIP Journal on Wireless Communication Networking 2018, 155. https://doi.org/10.1186/s13638-0181157-7.

Zhima, Z., Hu, Y., Piersanti, M., dkk. (2020). The Seismic Electromagnetic Emissions During the 2010 Mw 7.8 Northern Sumatra Earthquake Revealed by DEMETER Satellite. Frontiers in Earth Science, 8, Article 572393. https://doi.org/10.3389/feart.2020.572393. 